\title{
A CARBOCATIONIC 1,3-ALKENYL SHIFT
}

Englbert Bäuml, Gerlinde Kolberg and Herbert Mayr*

Institut für Chemie, Medizinische Universität zu Lübeck, Ratzeburger Allee 160, D-2400 Lübeck 1, Federal Republic of Germany

Summary: The Lewis acid catalyzed rearrangement $7 \rightarrow 13$ is explained by a carbocationic 1,3-alkenyl shift via the cyclobutylcarbinyl cation 10 .

The high tendency to undergo rearrangements is one of the characteristics of carbocations [1]. In acyclic systems, 1,2- $\mathrm{H}$ and alkyl migrations usually have small barriers, in many cases below $3-4 \mathrm{kcal} / \mathrm{mol}$ (eq. 1). If $\mathrm{X}$ corresponds to vinyl or phenyl, the bridged species 2 (cyclopropylcarbinyl cations or phenonium ions) are of ten more stable than the acyclic isomers 1 and 3 .

\section{Carbocationic 1,2-shifts}<smiles>[X]C(C)(C)[C+](C)C</smiles>

1

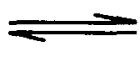<smiles>[X]C1(C)CCC1(C)C</smiles>

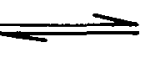<smiles>[X]C(C)(C)[C+](C)C</smiles>

(1)

In contrast to the innumerable examples of 1,2-migrations, only few cases of 1,3-hydride shifts have been observed [2]. We report now on a carbocationic 1,3-alkenyl migration, to our knowledge the first example of this type of rearrangement.

\section{Carbocationic 1,3-shifts}<smiles>[X]C1(C)[C+](C)C(C)(C)C1(C)C</smiles><smiles>C#C</smiles><smiles>[X]C12C[CH+]C(CC1)C2(C)C</smiles><smiles>C1=CC1</smiles><smiles>[X]C(C)(C)C(C)(C)[C+](C)C</smiles> 
When 7, the addition product of tetramethylallyl chloride with styrene [3], was treated with $\mathrm{SnCl}_{4}$ at $-90^{\circ} \mathrm{C}$ for $1 \mathrm{~h}, 9 \%$ of the cyclopentane derivative 12 were obtained besides the rearranged acyclic product $13(65 \%)$ and a trace of 14 [4,5]. Compound 13 was inert under the reaction conditions, and all attempts to convert 13 into 12 by treatment with Lewis acids at elevated temperature led to polymeric material.

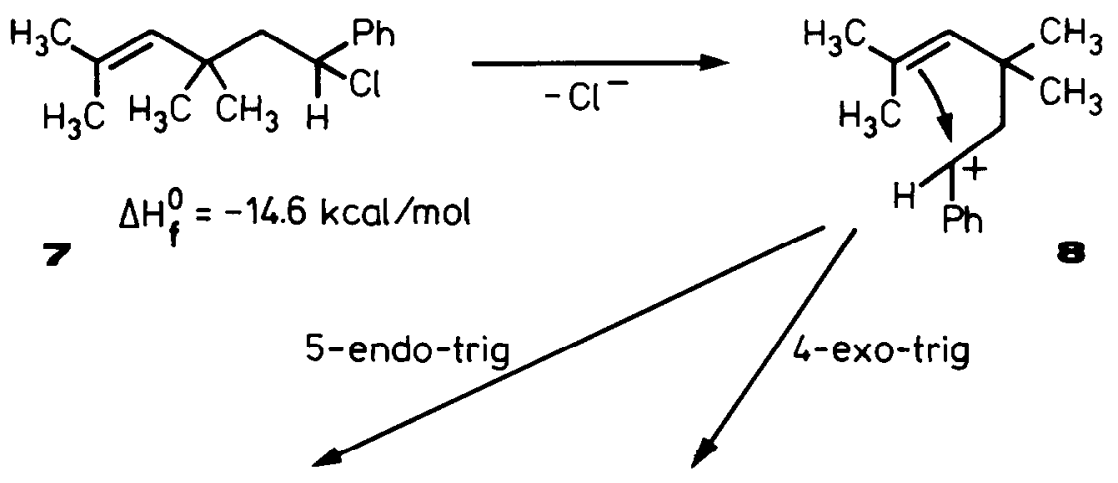<smiles>CC1(C)[CH+]C(C)(C)C(c2ccccc2)C1</smiles>

9<smiles>CC(C)Cl</smiles><smiles>CC1(C)CC(c2ccccc2)C(C)(C)C1Cl</smiles>

$\Delta H_{f}^{0}=-28.9 \mathrm{kcal} / \mathrm{mol}$<smiles>CC1(C)CC(c2ccccc2)C(C)(C)C1</smiles><smiles>[CH2-]C</smiles>

10

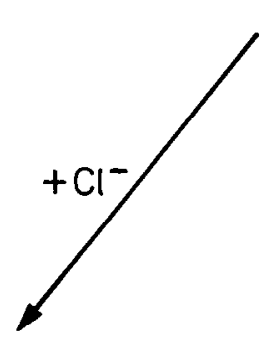<smiles>CC(C)=CC(C[C+](C)C)c1ccccc1</smiles>

11

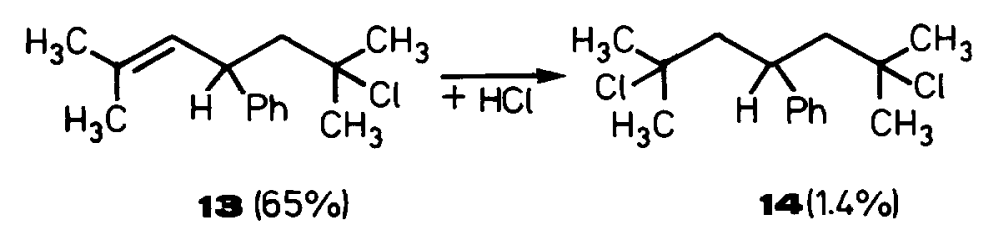
$\Delta H_{f}^{0}=-18.9 \mathrm{kcal} / \mathrm{mol}$ 
The reaction is suggested to proceed via cations 8 - 11. The initially generated benzyl cation 8 can undergo a 5-endo-trig or 4-exo-trig cyclization [6] to give the cyclic carbenium ions 9 or 10. Alternatively, the cyclopentyl cation 9 , which can be estimated to be thermodynamically more stable than 10 [3], may be formed via ring enlargement of 10 . The failure to detect five membered ring compounds different from 12 is explained by ion pairing effects, which inhibit 1,2-methyl shifts in 9. Ring cleavage of the cyclobutylcarbinyl cation 10 may either regenerate the cation 8 or give the carbenium ion 11 , the precursor of the 1,3-migration products 13 and 14 .

Heats of formation of the isomers 7,12 , and 13 have been obtained by force field calculations [7]. The calculated enthalpy differences are large enough that a change of the stability order $12>13>7$ by entropy contributions can be excluded. The lower ground state enthalpy of 13 compared with 7 can account for the fact that 13, once formed, cannot be converted into the thermodynamically most stable isomer 12 . The tertiary chloride derived from cation 10 was calculated to be less stable $\left(\Delta \mathrm{H}_{\mathrm{f}}^{0}=-12.2 \mathrm{kcal} / \mathrm{mol}\right.$ ) than the isomeric compounds 7, 12 and 13 in accord with the failure to detect derivatives of 10.

The extremely mild conditions $\left(-90^{\circ} \mathrm{C}\right)$, under which the cationic 1,3 -migration $7 \rightarrow 13$ took place, indicate this type of rearrangement to have a very low barrier if the intermediate cyclobutylcarbinyl cation is of comparable stability as its acyclic precursor.

Acknowledgment. We thank Ms. Gabriele Ulrichs for experimental assistance, the Deutsche Forschungsgemeinschaft and the Fonds der Chemischen Industrie for financial support.

\section{References and Spectral Data}

1) Reviews: a) Saunders, M.; Chandrasekhar, J.; Schleyer, P.v.R. in Rearrangements in Ground and Excited States (P. de Mayo, Ed.), Vol. I, Academic Press, New York, 1980, Chapt. 1. b) Kirmse, W.; Topics Curr. Chem. 1979, 80, 125. c) Vogel, P., Carbocation Chemistry, Elsevier, Amsterdam, 1985, Chapt. 8.

2) a) Okazawa, N.E.; Sorensen, T.S., Can. J. Chem., 1982, 60, 2180. b) Saba, J.A.; Fry, J.L., J. Am. Chem. Soc., 1983, 105, 533. c) Proudfoot, J.R.; Djerassi, C., J. Am. Chem. Soc., 1984, 106, 5613.

3) Mayr, H.; Klein, H.; Kolberg, G., Chem. Ber., 1984, 117, 2555.

4) As described in ref. 3, rearrangements of 8 during the preparation of 7 can be avoided, when the life time of 8 is reduced by adding a tetraalkylammonium chloride to the reaction mixture.

5) 1-Chloro-2,2,5,5-tetramethyl-3-phenyl-cyclopentane 12: $\mathrm{mp} 40-42^{\circ} \mathrm{C}$ (pentane). - ${ }^{1} \mathrm{H}$ $\operatorname{NMR}\left(\mathrm{CDCl}_{3}, 200 \mathrm{MHz}\right): \delta 0.73(\mathrm{~s}, 3 \mathrm{H}), 0.97(\mathrm{~s}, 3 \mathrm{H}), 1.17(\mathrm{~s}, 3 \mathrm{H}), 1.21(\mathrm{~s}, 3 \mathrm{H})$, $1.83\left(\mathrm{dd}, J_{\text {gem }}=13.1 \mathrm{~Hz}, J_{\text {trans }}=6.9 \mathrm{~Hz}, 1 \mathrm{H}, 4-\mathrm{H}\right), 2.21\left(t, J_{\text {gem }}=J_{\text {cis }}=13.2 \mathrm{~Hz}\right.$, $1 \mathrm{H}, 4-\mathrm{H}), 2.80\left(\mathrm{dd}, J_{c i s}=13.2 \mathrm{~Hz}, J_{\text {trans }}=6.9 \mathrm{~Hz}, 1 \mathrm{H}, 3-\mathrm{H}\right), 3.77(\mathrm{~s}, 1 \mathrm{H}), 7.1-$ 
$7.4(\mathrm{~m}, 5 \mathrm{H}) . \quad-{ }^{13} \mathrm{C} \mathrm{NMR}\left(\mathrm{CDCl}_{3}\right): \delta 16.5,26.7,28.3,31.6\left(4 \mathrm{q}, \mathrm{CH}_{3}\right), 38.5(\mathrm{~s}, \mathrm{C}-5)$, $43.4(t, c-4), 48.0(s, c-2), 51.3(d, c-3), 81.0(d, c-1), 126.6,127.9,128.8(3 \mathrm{~d}$, $\left.\mathrm{C}_{\mathrm{O}}, \mathrm{C}_{\mathrm{m}}, \mathrm{C}_{\mathrm{p}}\right), 139.3\left(\mathrm{~s}, \mathrm{C}_{\mathrm{i}}\right)$. - 6-Chloro-2,6-dimethyl-4-phenyl-2-heptene 13: bp 55 $62^{\circ} \mathrm{C}$ (bath) $/ 0.025$ mbar. - ${ }^{1} \mathrm{H} \mathrm{NMR}\left(\mathrm{CDCl}_{3}, 200 \mathrm{MHz}\right): \delta 1.48(\mathrm{~s}, 3 \mathrm{H}), 1.53(\mathrm{~s}, 3 \mathrm{H})$, $1.67(\mathrm{~d}, \underline{J}=1.3 \mathrm{~Hz}, 3 \mathrm{H}), 1.70(\mathrm{~d}, \underline{J}=1.4 \mathrm{~Hz}, 3 \mathrm{H}), 2.14,2.24,3.88$ (ABX-system of $5-\mathrm{H}_{2}$ and $4-\mathrm{H}$ with $J_{A B}=14.4 \mathrm{~Hz}, J_{A X}=7.3 \mathrm{~Hz}, J_{B X}=5.3 \mathrm{~Hz}$, and $\left.J_{X}, 3=9.6 \mathrm{~Hz}\right), 5.32$ (br. $\mathrm{d}, \underline{\mathrm{J}}=9.6 \mathrm{~Hz}, 1 \mathrm{H}, 3-\mathrm{H}), 7.1-7.4(\mathrm{~m}, 5 \mathrm{H}) .-{ }^{13} \mathrm{C} \mathrm{NMR}\left(\mathrm{CDCl}_{3}\right): \delta 18.1,25.8$ $\left(2 \mathrm{q},\left(\mathrm{CH}_{3}\right)_{2} \mathrm{C}=\right), 32.9,33.4\left(2 \mathrm{q},\left(\mathrm{CH}_{3}\right)_{2} \mathrm{CCl}\right), 41.8(\mathrm{~d}, \mathrm{C}-4), 52.9(\mathrm{t}, \mathrm{C}-5), 71.4(\mathrm{~s}$, $c-6), 125.8(d, C-3), 127.2,128.5\left(2 d, C_{o}, C_{m}\right), 129.6\left(d, C_{p}\right), 130.7(s, C-2), 146.4$ $\left(s, C_{j}\right)$. - 2,6-Dichloro-2,6-dimethyl-4-phenyl-heptane 14: bp $50-56^{\circ} \mathrm{C}$ (bath) $/ 0.004$ mbar. - ${ }^{1} \mathrm{H} \mathrm{NMR}\left(\mathrm{CDCl}_{3}, 200 \mathrm{MHz}\right): \delta 1.37,1.45\left(2 \mathrm{~s}, 12 \mathrm{H}, 4 \mathrm{CH}_{3}\right), 2.19,2.25,3.31$ $\left(\mathrm{A}_{2} \mathrm{~B}_{2} \mathrm{X}\right.$-system of $3-\mathrm{H}_{2}, 5-\mathrm{H}_{2}$ and $4-\mathrm{H}$ with $\left.\underline{J}_{A B}=14.5 \mathrm{~Hz}, \underline{J}_{A X}=8.7 \mathrm{~Hz}, J_{B X}=3.6 \mathrm{~Hz}\right)$, $7.27(\mathrm{mc}, 5 \mathrm{H})$.

6) Baldwin, J.E., J. C. S. Chem. Commun., 1976, 734.

7) a) Allinger, N.L., J. Am. Chem. Soc., 1977, 99, 8127. b) Gajewski, J.J.; Gilbert, K.E., "Molecular Mechanics Package (MS-DOS Computers)", Serena Software, Bloomington, Indiana.

(Received in Germany 4 November 1986) 